\title{
Comparative evaluation of reproductive performance of artificially inseminated and naturally mated Nigeria indigenous hens treated with clomiphene citrate
}

\author{
Urom, S. M. O. C
}

College of Animal Science and Animal Production, Michael Okpara University of

Agriculture, Umudike, Umuahia, Abia State, Nigeria

Corresponding Author: scholarurom@yahoo.com, and scholtica@gmail.com

09037532340,08036343611

\section{Abstract}

The research was conducted for 90 days using 96 and 16 Nigeria indigenous hens and cocks respectively sexually matured (24 and 26 weeks old) to comparatively evaluate the effect of clomiphene citrate on the reproductive performance of Nigerian indigenous birds. The birds were divided into 2 groups of 48 hens per group respectively as group A and group B. Group $A$ were artificially inseminated while group $B$ birds were naturally mated. Each group was divided into 4 treatment groups of 12 hens per treatment. Clomiphene citrate was administered at $0 \mathrm{mg}$ (control), 10mg, 20mg and 30mg levels to the treatment groups represented as $T_{I A I,} T_{2 A I,} T_{3 A I}$ and $T_{4 A I}$ and $T_{I N M}, T_{2 N U}, T_{3 N N}$ and $T_{4 N M}$ for artificially inseminated and Naturally mated hens respectively and $T_{1 C} T_{2 C} T_{3 C}$ and $T_{46}$ for the cocks. The birds were fed adlibitum with breeder's mash for hens and growers mash for cock while water was served regularly. Seven days after clomiphene citrate was administered. Birds for natural mating were paired with their respective cocks according to their treatment groups, while those for artificial insemination were inseminated using cocks in the same treatment group. The ration was 2:12. The result of this study indicated higher productivity in artificially inseminated hens between (50-76 eggs) than naturally mated hens which produce between 42-63 eggs within this period. Artificial insemination also showed higher fertility of (62 to $85.25 \%$ ) than the naturally mated that recorded between $34.88 \%$ to $78.5 \%$ fertility but the naturally mated recorded hatchability of between $53.35 \%$ and $90.90 \%$ while artificially inseminated hens recorded between $46.15 \%$ and $90.32 \%$. Artificial inseminated birds recorded between $3.7 \%$ and $33.85 \%$ and $3.57 \%$ and $20.15 \%$ dead in germ and dead in shell respectively, while naturally mated hens recorded between $3.78 \%$ and $19.21 \%$, and $2.01 \%$ and $15.79 \%$ in dead in germ and dead in shell respectively. The result of this study shows that artificial inseminated birds treated with clomiphene citrate encourages egg production and fertility.

Keywords: Insemination, natural mating, hatchability, fertility

\section{Introduction}

Poultry egg constitute one of the most valuable source of animal protein recommended for human consumption, and offers means of solving the problems of animal protein shortage especially in rural areas in many African countries (Olawoyin, 2006). Fertility, hatchability, egg production and growth are economically important traits in local poultry production system, since the developed chickens are kept for both meat and egg production.
Breeders always aim at conserving and increasing the productivity efficiency of native chicken genetically for economic growth (RSH, 2014).the supply of day old chicks is very important for the success of the poultry production chain (King'ori, 2011). Fertility and hatchability are two major parameters that highly influence the demand for day old chicks.

In Nigeria, the local chickens are widely distributed in the rural areas, where they are kept by the natives principally as source of 
protein and income. Egahi et al. (2010) noted that the local chicken has a unique adaptive feature that predisposes it to adapt to the local environment better than their exotic counterpart. The Nigeria indigenous layers are suitable for the development of layers strain for tropical environment (Adekunle, 2012). This can be attributed to their possession of inherent advantages which include better flavor of meat and egg, high degree of adaptability to prevailing condition, high genetic variance in their performance, hardiness, disease tolerance, ease of raring and ability to breed naturally (Ige, 2013). Reports have also shown that the indigenous chicken possesses great potentials for genetic improvement through breeding programme such as selection and or cross breeding (Nwosh et al., 1983; Nwosu and Omeje, 1988).

Reproductive efficiency among domesticated poultry is still very low in developing countries. These differences have given rise to the development of the numerous techniques of reproduction such as the use of fertility drugs e.g clomiphene citrate, Perganol and use of Artificial insemination techniques Fertility drugs have been used extensively to encourage livestock production as it has been reported by Terblance and Huston (2000) and Periera etal. (2000).

It is believed that the result of this study involving the above mentioned technique will provide useful information that will foster better understanding with the view to enhancing their contribution to the livelihood of farmers.

\section{Materials and Methods \\ Location of the study}

The study was carried out in the poultry unit of the teaching and research farm of Michael Okpara University of Agriculture, Umudike located within the rain-forest agro-ecological zone of South-Eastern
Nigeria. The area is on latitude $05^{\circ} 28^{\prime}$ North, longitude $07^{\circ} 33^{\prime}$ East and at an altitude of $122 \mathrm{~m}$ above sea level. The location has annual precipitation range of 1700-2000 $\mathrm{mm}$, average temperature range of $22-28^{\circ} \mathrm{c}$ and average relative humidity of $55 \%$.

\section{Experimental Animals and Management}

The experiment involved 96 normal feathered local hens and 16 local cocks of $24-25$ weeks of ages. The 96 hens were divided into 2 groups of 48 hens per group; each group was further divided into 4 treatment groups of 12 hens per group. The 16 cocks were also divided into 2 groups of 8 cocks per group. Each of these 2 groups of cocks was further divided into 4 treatment groups of 2 birds per group. Each of these 2 group were represented as group A and B respectively for Artificially inseminated and naturally mated hens. These birds were reared in battery cages and were tagged for identification. The levels of clomiphene citrate received as treatment were 0mg(control), $10 \mathrm{mg}, 20 \mathrm{mg}$ and $30 \mathrm{mg}$ represented as $\mathrm{T}_{1 \mathrm{AI}}, \mathrm{T}_{2 \mathrm{AI}}, \mathrm{T}_{3 \mathrm{AI}}$ and $\mathrm{T}_{4 \mathrm{AI}}$ and $\mathrm{T}_{1 \mathrm{NM}}, \mathrm{T}_{2 \mathrm{NM}}, \mathrm{T}_{3 \mathrm{NN}}$ and $\mathrm{T}_{4 \mathrm{NM}}$ and $\mathrm{T}_{1 \mathrm{CNM}}, \mathrm{T}_{2 \mathrm{CNM}}$, $\mathrm{T}_{3 \mathrm{CNN}}$ and $\mathrm{T}_{4 \mathrm{CNM}}$ for artificially inseminated, Naturally mated hens, cock for artificially inseminated and cocks for naturally mated respectively. Treatment $\mathrm{T}_{1}$ is the control.

Breeders mash was fed to the hens while grower mash was served to the cocks adlibitum and clean water was regularly served. Clomiphene citrate was given through water for 5 days. Seven days after treatment, the cocks in naturally mated were paired according to their treatment groups for natural mating ( 2 cocks per 12 hens) and were monitored. The artificial insemination commenced as well.the artificial insemination commenced as well.

\section{Data collection}

Egg collection began 3 days after natural mating and artificial insemination. Eggs 


\section{Urom}

were collected daily to avoid evaporation of the internal egg content due to intensity of sunshine in the tropics. Only sound eggs without cracks and discolouration were collected. Physically shaped and sound eggs were collected for the study.

Parameters taken include:

Egg Number - Total number of eggs laid by each treatment group during the expected period

Percentage fertility $=$

Number of fertile egg x 100

Number of eggs

Percentage infertility $=$

Number of infertile eggs x 100

Number of eggs
Percentage hatchability $=$

Number of chicks hatched $\times 100$

Number of fertile eggs

Percentage dead in germ $=$

Number of dead in germ $\times 100$

Number of fertile eggs

Percentage dead in shell $=$

Number of dead in shell $\times 100$

Number of fertile eggs

These parameters were obtained by procedure described by Adedeji et al., (2015). Data collected were analyzed using simple descriptive statistic comprising of ratios and percentages.

Table 1: percentage dead in shell of artificial inseminated Nigerian indigenous Hens treated with Clomiphene citrate

\begin{tabular}{lllll}
\hline Treatment & $\mathbf{T}_{\mathbf{1}}$ & $\mathbf{T}_{\mathbf{2}}$ & $\mathbf{T}_{\mathbf{3}}$ & $\mathbf{T}_{\mathbf{4}}$ \\
& $\mathbf{0 . 0} \mathbf{m g}$ & $\mathbf{1 0 m g}$ & $\mathbf{2 0 m g}$ & $\mathbf{3 0 m g}$ \\
\hline Number of eggs collected & 50.00 & 72.00 & 76.0 & 51 \\
Percentage fertility & $62.00 \%$ & $79.17 \%$ & $75.0 \%$ & $88.25 \%$ \\
Percentage infertility & $90.32 \%$ & $46.15 \%$ & $57.87 \%$ & $71.11 \%$ \\
Percentage dead in germ & $3.76 \%$ & $33.85 \%$ & $21.98 \%$ & $23.78 \%$ \\
Percentage dead in shell & $3.57 \%$ & $20.15 \%$ & $16.21 \%$ & $5.10 \%$ \\
\hline
\end{tabular}

Table 2: Number of eggs, percentage fertility, percentage hatchability, percentage dead in germ and percentage dead in shell of Naturally mated Nigeria indigenous Hens treated with Clomiphene citrate

\begin{tabular}{lllll}
\hline Treatment & $\mathbf{T}_{\mathbf{1 N M}}$ & $\mathbf{T}_{\mathbf{2 N M}}$ & $\mathbf{T}_{\mathbf{3 N M}}$ & $\mathbf{T}_{\mathbf{4 N M}}$ \\
\hline No. of eggs & 42 & 63 & 61 & 43 \\
Percentage fertility & $47.0 \%$ & $78.6 \%$ & $41.0 \%$ & $34.9 \%$ \\
Percentage infertility & $53.0 \%$ & $21.4 \%$ & $59.0 \%$ & $65.1 \%$ \\
Percentage hatchability & $83.0 \%$ & $90.9 \%$ & $84.0 \%$ & $53.3 \%$ \\
Percentage dead in germ & $8.3 \%$ & $4.1 \%$ & $3.8 \%$ & $19.2 \%$ \\
Percentage dead in shell & $5.0 \%$ & $2.0 \%$ & $4.2 \%$ & $15.8 \%$ \\
\hline
\end{tabular}

\section{Results and Discussion}

The percentage fertility and hatchability of artificially inseminated hens is presented on Table 1, while that of naturally mated is presented on Table 2 .

In artificially inseminated groups, Treatment $_{1}$ had 50 number of eggs, $\mathrm{T}_{2}$ recorded 72 number of eggs, $\mathrm{T}_{3}$ recorded 76.0 number of eggs and 51 number of eggs in $\mathrm{T}_{4}$, while in naturally mated, $\mathrm{T}_{1}$ recorded 42 eggs, $\mathrm{T}_{2}(63), \mathrm{T}_{3}(61)$ and $\mathrm{T}_{4}(43)$. From the above, naturally mated hens were not comparable with artificially inseminated hens in productivity, since artificially inseminated hens ranked higher than the naturally mated in the number of eggs laid. The percentage fertility in Artificial inseminated was also greater than the naturally mated. The percentage fertility in artificially inseminated hen are $62 \%$, $79.17 \%, 75.0 \%$ and $88.25 \%$ for $\mathrm{T}_{1 \mathrm{AI}}, \mathrm{T}_{2 \mathrm{AI}}, \mathrm{T}_{3 \mathrm{AI}}$ and $\mathrm{T}_{4 \mathrm{AI}}$ respectively while in naturally 
mated, the percentage fertility are: $47 \%$, $78.6 \%, 41 \%$ and $34.9 \%$ for $\mathrm{T}_{1 \mathrm{NM}}, \mathrm{T}_{2 \mathrm{NM}}, \mathrm{T}_{3 \mathrm{NN}}$ and $\mathrm{T}_{4 \mathrm{NM}}$ respectively. Hatchability was more in naturally mated as it is recorded in $\mathrm{T}_{1 \mathrm{NM}}(83.0 \%) \mathrm{T}_{2 \mathrm{NN}}(90.0 \%), \mathrm{T}_{3 \mathrm{NN}}(84.0 \%)$ and $\mathrm{T}_{4 \mathrm{NM}}(53.3 \%)$ except in the control where the hatchability was recorded $(90.34 \%)$ higher than naturally mated. the percentage dead in germ and dead in shell were higher in Artificially inseminated Naturally mated hens than Naturally mated hens. In Naturally mated hens, in dead germ $\mathrm{T}_{1 \mathrm{NM}}$ $(8.3 \%), \mathrm{T}_{2 \mathrm{NN}}(4.1 \%), \mathrm{T}_{3 \mathrm{NM}}(3.8 \%)$ and $\mathrm{T}_{4 \mathrm{NM}}$ $(19.2 \%)$ while in artificially inseminated the following values were recorded, $\mathrm{T}_{1 \mathrm{AI}}(3.76), \mathrm{T}_{2 \mathrm{AI}}(33.85), \mathrm{T}_{3 \mathrm{AI}}(21.98)$ and $\mathrm{T}_{4 \mathrm{AI}}(23.78)$. The percentage dead in shell in Artificially inseminated hens ranged between $(3.57 \%$ and $20.15 \%)$, while in Naturally mated the range fall between $2.0 \%$ and $15 \%$.Percentage fertility in artificial inseminated in this work is within the range reported by Ajayi et al. (2008). Also the percentage hatchability fell within the range of 46.15 to $90.32 \%$ and percentage dead in germ of $3.85 \%$ and $23.81 \%$ recorded by Ajayi (2008). The result of this work shows that fertility was highest in artificially inseminated birds, while hatchability was higher in naturally mated hens.

The recorded values in percentage dead in shell and dead in germs where higher in artificially inseminated hens.

\section{Conclusion}

The recorded values in percentage dead in shell and dead in germ were higher in artificially inseminated hens. From the above results, it could be deduced that clomiphene citrate encouraged egg production and fertility when the birds are artificially inseminated and at $10 \mathrm{mg}$ clomiphene citrate administration.
References

Adekunle, M. A., Sunday, O. P., Michael, O. O., Christian, O. N., Adeyemi, M. B. and Olufumilayo, A. A 2012. Effect of cross breeding on fertility, hatchability and embrayonic mortality of Nigerian local chickens. Tropic Animal Health Prod. (2012) 505-510.

Adedokun, S. A. and Sonayia, E. B 2001. comparison of the performance of Nigerian indigenous chichens from three agro-ecological zones livestock Research, for rural $\mathrm{D}$ e $\mathrm{v}$ e 1 o $\mathrm{p}$ m e $\mathrm{n} t$. http://www.cipar.org.co/irrd 1312/added/132.htm.

Egahi, J. O., Dim, N. I., Momoh, O. M. and Gwaza, D. S. 2010. Variations in Qualitative Traits in the Nigerian local chicken. International Journal of poultry Science (10): 978-979, 2010. ISSN 1682-8356

Ige, A. O. 2013. Relationship between Body weight and growth traits of cross bred Fulani Ecotype chicken in Derived savannah zone of Nigeria. International Journal of Applied Agricultural and Apicultural Research IJAAAR. 157-166 (C) Faculty of Agricultural Sciences LAUTECH, Ogbomoso, Nigeria 2013

King Ori, A. M., 2011. Review of the Fadors that influence Egg fertility and Hatchability in poultry, International Journal of poultry science (6): 483-492, 2011 ISSN 1682-8356C Asian Network for Scientific information

Nwosu, C. C., Gowen, F. A., Obioha, F. C., Akpan, I. A. and Oluora, G. I. 1983. A Biochemical study of the confirmation of the native chicken, Nigeria J. Avian-prod. (1 and 2) 141-146 
Omeje, S. I. I. 1985. Short term egg production in local chicken and its crosses with Gold-ink under two.

Olawoyin, O. O. 2006. Evaluation of performance and adaptability of the local Nigerian and exotic Harco cockerels in the humid tropical zones. Tropical Journal of Animal Sciences (1): 63-71
Pereira, R. J. T. A., Sohnry, B. and Holz, W. 2000. Non-surgical collection of goods embryo Proc. $13^{\text {th }}$ Int. congri. Sydney, Australia Pp 18-23

Terblance, S. J. and Humton T. 2000. effect of Fluxrie meghmine or and plansma concentration of androgens and leuteinizing hormone during sexual development in the cockerel. $J$. endocinal, 74: 457-469

Received: 25 ${ }^{\text {th }}$ August, 2016 Accepted: 12 $2^{\text {th }}$ March, 2017 